IKONOMIKA :Journal of Islamic Economics and Business

Volume 2, No I (20I7)

ISSN: 2527-3434 (PRINT) - ISSN: 2527-5I43 (ONLINE)

Page : $19-40$

\title{
Penerapan PSAK NO. I02 Atas Transaksi Murabahah: Studi Pada Baitul Maal Wa Tamwil Di Depok, Jawa Barat
}

\author{
Rani Febrian', Sepky Mardian ${ }^{2}$ \\ Sekolah Tinggi Ekonomi Islam SEBI \\ sepky.mardian@gmail.com²
}

\begin{abstract}
This study aims to determine the accounting treatment of murabahah (recognition, measurement, presentation and disclosure) in accordance with PSAK no. IO2. BMT in Depok was studied. The descriptive analysis with qualitative and quantitative approaches wasused to deploythe questionnaires to respondents. The study showed that the accounting treatment of murabahah in BMT Depok is not all adopted PSAK no. IO2 properly. The average value of the percentage only reached $68.4 \%$. There are weaknesses in the educational background of the respondents were limited to the knowledge of transaction records BMT.
\end{abstract}

Keywords: Baitul Maal Wa Tamwil, PSAK IO2, Murabahah Transaction.

\begin{abstract}
Abstrak
Penelitian ini bertujuan untuk menentukan perlakuan akuntansi atas murabahah (rekognisi, pengukuran, gambaran, dan pengungkapan) terkait dengan Pedoman Standar Akuntansi dan Keuangan (PASK) No. IO2 pada Baitul maal wa tamwil (BMT) di Depok. Pendekatan yang dipergunakan dalam penelitian ini ialah analisis deskriptif baik kualitatif maupun kuantitatif dengan melakukan penyebaran kuesioner kepada responden. Hasil penelitian menunjukkan bahwa tidak semua BMT di Depok telah mengadopsi PSAK No. IO2 pada perlakuan akuntansi atas transaksi murabahah. Nilai rata-rata yang dicapai hanya $68.4 \%$. Terdapat kelemahan pada aspek latar belakang pendidikan responden yang mengakibatkan terbatasnya pengetahuan atas catatan transaksi di BMT.
\end{abstract}

Kata Kunci: Baitul Maal Wa Tamwil, PSAK IO2, Transaksi Murabahah 


\section{A PENDAHULUAN}

Kelahiran BMT merupakan realisasi rekomendasi silahturahmi kerja nasional (SILAKNAS) Ikatan Cendikiawan Muslim Indonesia (ICMI) tahun 1994. Rekomendasi ini dilatar belakangi oleh eksitensi Bank Syariah, hal ini Bank Muamalat Indonesia yang sudah beroperasi sejak tahun 1992, namun belum mampu memberikan harapan bagi semua lapisan masyarakat terutama pengusaha mikro kecil.Hal ini disebabkan karena sebagai lembaga keuangan perbankan Bank Muamalat sangat terikat dengan peraturan-peraturan perbankan yang sangat kaku. Oleh karena itu dipandang perlu mendirikan Lembaga Keuangan Syariah alternatif yang relatif kecil dan fleksibel untuk malayani usaha mikro maka didirikanlah Lembaga Keuangan Mikro Syariah (LKMS) yaitu Baitul Mal Wat Tamwil (BMT) yang operasionalnya berdasarkan prinsip syariah (Didiek, 20I3)

BMT sebagai lembaga keuangan yang ditumbuhkan dari peran masyarakat secara luas tidak ada batasan ekonomi, sosial, bahkan agama. Semua komponen masyarakat dapat berperan aktif dalam membangun sebuah sistem keuangan yang lebih adil dan mampu menjangkau lapisan pengusaha yang terkecil sekalipun. (Mustofa, 20I4). Keberadaan BMT pada awalnya sebagai lembaga ekonomi rakyat yang membantu masyarakatmenengah bawah, kegiatan utama dari BMT adalah pengembangan usaha mikro terutama mengenai bantuan permodalan.Untuk melancarkan usaha pembiayaan BMT menghimpun dana dari masyarakat lokal. Peran umum yang dilakukan BMT adalah melakukan pembinaan dan pendanaan berdasarkan prinsip syariah yang mana merupakan salah satu upaya untuk menjalankan prinsip-prinsip syariah dalam kehidupan ekonomi masyarakat.

Keberadaan BMT di Indonesia telah menjadi alternatif penyedia jasa keuangan untuk pembiayaan mikro Islam. Dimana ada 3 hal yang mendasari pernyataannya tersebut. Pertama, BMT didirikan di sebuah komunitas kecil. Kedua, hal itu dibuktikan bahwa BMT telah memberantas praktek rentenir. Sebelumnya, praktek rentenir telah menjadi alternatif pembiayaan bagi UMKM karena tidak mudah untuk memenuhi persyaratan bank (bankable) jika mereka ingin berurusan dengan bank. Ketiga, BMT bisa bertahan ketika krisis keuangan global melanda stabilitas perekonomian Indonesia pada tahun 2008.(Wardiwiyono, 20I2)

Belum adanya data akurat mengenai pertumbuhan jumlah BMT atau Baitul Maal Wa Tamwil, selain karena entitas BMT masih berada di bawah Kementerian Koperasi dan UMKM, BMT masih dianggap pemain minor dalam industri keuangan syariah di Indonesia. Meskipun demikian, BMT terus mengalami pertumbuhan. Ketua Asosiasi BMT se Indonesia (Absindo), Aries Muftie menyatakan bahwa pada akhir tahun 2014 terdapat lebih dari 5.500 BMT di 
Indonesia. Kemudian, menurut Setyo Heriyanto selaku Deputi Bidang Kelembagaan dan UMKM Kementerian Koperasi dan UMKM perkembangan kinerja dari BMT secara nasional di tahun 20I5 telah mencapai aset sebesar Rp 4,7 triliun dan jumlah pembiayaan sebesar Rp3,6 triliun.Usaha Mikro Kecil dan Menengah (UMKM) sangat penting bagi perkembangan perekonomian negara karena salah satu upaya dalam percepatan pertumbuhan ekonomi adalah dengan perbaikan di sektor keuangan melalui perluasan akses dalam penyediaan pembiayaan untuk sektor UMKM.

BMT juga merupakan lembaga keuangan Syariah non bank yang jumlah lebih banyak dibandingkan lembaga-lembaga keuangan syariah lainnya. Perkembangan tersebut terjadi tidak lain karena kinerja BMT yang selalu meningkat sepanjang tahunnya dan juga sistem yang digunakanBMT sangat membantu masyarakat.Di balik peranannya yang sangat strategis dalam pemberdayaan ekonomi kerakyatan yang dimaksud, tidak sedikit di antara BMT yang masih menghadapi kendala, sehingga kurang mampu menjalankan peranan dan fungsinya dengan optimal. Kendala tersebut bisa bersifat internal maupun eksternal. Kendala internal mencakup lemahnya kualitas sumber daya manusia dalam pemahaman laporan keuangan yang sesuai dengan PSAK serta terbatasnya sumber pendanaan yang ada di dalam suatu instansi BMT. Sedangkan kendala eksternal yaitu rendahnya kepedulian masyarakat dan pemerintah terhadap lembaga keuangan mikro syariah ini.

Di lain pihak, pemerintah pun belum membuat kebijakan yang khusus mengatur keberadaan BMT yang berkaitan tentangpenyediaan dana penjamin, perlindungan, pengawasan dan berbagai regulasi lainnya, sehingga peraturan yang ada masih bersifat parsial. Sehinggahingga saat ini, lembaga ini tidak memiliki undang-undang resmi dari pemerintah.Pegawai atau karyawan merupakan sumber daya manusia yang memiliki peran penting untuk keberlangsungan BMT. Oleh karena ituPendidikan dan pengalaman kerja pegawai akuntansi sangatlah penting karena dapat memberikan kontribusi besar terhadap BMT itu sendiri.Salah satunya pengetahuan tentang akuntansi karena akuntansi itu sangat butuh, untuk pencatatan, pencatatan mengahsilkan laporan keuangan, laporan keuangan yang mencerminkan kinerja BMT.

Pengetahuan yang luas tentang akuntansi syariah dapat membawa BMT menjadi BMT yang berstandar dan dapat dipercaya. Karena ilmu akuntansi akan diimplementasikan dalam pencatatan transaksi yang terjadi setiap harinya di BMT, yang mana akan menghasilkan laporan keuangan. Laporan keuangan akan menggambarkan kinerja management dan operasional BMT tersebut.Sehingga 
sangat dibutuhkan pengetahuan dan kemampuan akuntansi yang berkualitas sehingga bisa menciptakan laporan keuangan yang sesuai dengan standar yang berlaku.

Penelitian sebelumnya oleh Pratiwi dan Septiarini (20I4) menunjukkan bahwa perkembangan BMT didominasi oleh produk jual beli atau murabahah. Murabahah sebagai skema pembiayaan yang paling banyak diminati oleh nasabah ternyata masih terdapat kekurangan dalam hal proses pencatatan akuntansi.BMT Rahmat Syariah menerapkan murabahah bil wakalah dimana pembelian barang diwakilkan kepada mitra. BMT Rahmat Syariah memberikan sejumlah uang sesuai dengan yang tertera pada perjanjian akad pembiayaan. Sesuai dengan PSAK I02, seharusnya ketika penyerahan uang pembelian barang BMT Rahmat Syariah melakukan pencatatan atas transaksi murabahah bil wakalah tersebut dan ketika barang yang dimaksud oleh mitra sudah terbeli seharusnya terjadi pengakuan persediaan barang yang diakui sebesar biaya perolehan barang tersebut. Namun tidak terjadi pencatatan dan pengakuan terkait pembelian barang secara wakalah tidak pula diakui adanya persediaan aset murabahah. Ketika akad disepakati, BMT Rahmat Syariah baru melakukan pencatatan terkait pembiayaan yang diajukan oleh mitra.

\section{B. KAJIAN KEPUSTAKAAN Praktik Murabahah di LKMS (BMT)}

Di Indonesia, aplikasi jual beli murabahah pada perbankan syariah di dasarkan pada Keputusan Fatwa (DSN) Majelis Ulama Indonesia (MUI) dan peraturan Bank Indonesia (PBI), namun demikian dalam praktiknya tidak ada keragaman model penerapan pembiayaan murabahah karena beberapa faktor yang melatarbelakangi (Azharuddin, 20I4).

Transaksi murabahah yang dilakukan di BMT, lebih sering digunakan untuk pembiayaan yang ditujukan kepada nasabah untuk tambahan modal kerja. Seperti pembiayaan untuk memperluas usaha. Di dalam akad pembiayaan murabahah di BMT berdasarkan pada asas jual-beli, BMT bertindak sebagai penjual dan mitra usaha sebagai pembeli atau nasabah. Harga jual ditentukan berdasarkan harga beli dasar ditambah mark-up sesuai dengan kesepakatan antara BMT dengan mitra usaha. Hal ini merupakan pengertian pembiayaan murabahah yang merupakan jasa penyaluran dana yang dilakukan oleh BMT.

Dalam praktek pembiayaan murabahah di BMT setelah dana di transfer ke rekening nasabah, maka sudah sepenuhnya menjadi urusan nasabah. Uang itu digunakan untuk tambahan modal kerja, seperti perluasan usaha, ataupun untuk 
pembelian kendaraan guna memperlancar usahanya. Semua itu bukan menjadi urusan dari pihak BMT. Pihak BMT hanya berhak menerima angsuran pelunasan pembiayaan murabahah ditambah dengan margin yang telah ditentukan dan disepakati oleh nasabah.Penggunaan dana yang digunakan oleh nasabah, dilakukan setelah akad pembiayaan murabahah dilakukan dan dalam hal ini pula, hanya pengucapan secara lisan dari pihak BMT kepada nasabah untuk menggunakan dana tersebut sesuai apa yang diajukan di awal permohonan pembiayaan murabahah. Adanya penggunaan media wakalah yang tertulis dalam surat pelimpahan kekuasaan dari pihak BMT kepada nasabah. Dalam hal pembeliaan barang, nasabah hanya mengajukan surat untuk menyatakan keterangan barang apa saja yang akan dibelinya sebelum pembiayaan dilaksanakan.

Dalam prakteknya BMT memberikan kewenangan sepenuhnya kepada nasabah pembiayaan, untuk membeli barang yang diinginkannya sendiri karena BMT menganggap nasabah lebih tahu apa yang paling penting yang harus dibelanjakan/ dibutuhkan serta mempermudah pihak BMT. Hal ini semua terjadi setelah penentuan jumlah angsuran dan margin. Sehingga secara prinsip BMT menjual barang yang belum dalam kepemilikannya.

\section{Perlakuan Akuntansi Murabahah diLKS berdasarkan PSAK I02}

Baitul Maal wa Tamwil (BMT) menyalurkan dana dalam bentuk jual beli dalam pembayaran ditangguhkan adalah penjualan barang dari BMT kepada nasabah, dengan harga ditetapkan sebesar biaya perolehan barang ditambah margin keuntungan yang disepakati untuk keuntungan BMT. Dalam murabahah BMT bertindak sebagai penjual dan juga pembeli, sebagai pembeli BMT membeli barang kepada pemasok untuk dijual kepada nasabah. Perlakuan akuntansi murabahah di BMT berdasarkan PSAK I02 yang berhubungan dengan pengakuan, pengukuran, penyajian, dan pengungkapkan murabahah (IAI, 2009).

Berdasarkan PSAK IO2 akuntansi murabahah pengakuan, pengukuran, penyajian, dan pengungkapan akuntansi untuk penjual adalah sebagai berikut: Pertama, Pada saat perolehan, aset murabahah diakui sebagai persediaan sebesar biaya perolehan. Kedua, Pengukuran aset murabahah setelah perolehan adalah sebagai berikut: (a) Jika murabahah pesanan mengikat: dinilai sebesar biaya perolehan dan jika terjadi penurunan nilai aset karena usang, rusak, atau kondisi lainnya sebelum diserahkan kenasabah, penurunan nilai tersebut diakui sebagai beban dan mengurangi nilai aset. (b) Jika murabahah tanpa pesanan atau murabahah pesanan tidak mengikat: dinilai berdasarkan biaya perolehan atau nilai bersih yang dapat direalisasi, mana yang lebih rendah dan jika nilai bersih yang 
dapat direalisasi lebih rendah dari biaya perolehan maka selisihnya diakui sebagai kerugian.

Ketiga, diskon pembelian aset murabahah diakui sebagai berikut: (a) Jika terjadi sebelum akad murabahah maka sebagai pengurangan biaya perolehan aset murabahah. (b) Jika terjadi setelah akad murabahah dan sesuai akad yang disepakati maka bagianyang menjadi hak nasabah dikembalikan kepada nasabah jika nasabah masih berada dalam proses penyelesaian kewajiban atau kewajiban kepada nasabah jika nasabah telah menyelesaikan kewajiban. (c) Jika terjadi setelah akad murabahah dan sesuai akad yang menjadi bagian hak lembaga keuangan syariah diakui sebagai tambahan keuntungan murabahah. (d) Jika terjadi setelah akad murabahah dan tidak diperjanjikan dalam akad diakui sebagai pendapatan operasional lain.

Keempat, kewajiban penjual kepada pembeli atas pengembalian diskon pembelian akan tereliminasi pada saat: (a) Dilakukan pembayaran kepada pembeli sebesar jumlah potongan setelah dikurangi dengan biaya pengembalian. (b) Dipindahkan sebagai dana kebajikan jika pembeli sudah tidak dapat dijangkau oleh penjual. Kelima, potongan angsuran murabahah diakui sebagai berikut: (a) Jika disebabkan oleh pembeli yang membayar secara tepat waktu, maka diakui sebagai pengurang keuntungan murabahah. (b) jika disebabkan oleh penurunan kemampuan pembayaran pembeli, maka diakui sebagai beban. Keenam, pengakuan keuntungan. Keuntungan murabahah diakui: (a) Pada saat terjadinya akad murabahah jika dilakukan secara tunai atau secara tangguh sepanjang masa angsuran murabahah tidak melebihi satu periode laporan keuangan. (b) Selama periode akad secara proporsional jika akad melampaui satu periode keuangan.

Ketujuh, Potongan angsuran murabahah diakui sebagai berikut: (a) Jika disebabkan oleh pembeli yang membayar secara tepat waktu diakui sebagai pengurangan keuntungan murabahah. (b) Jika disebabkan oleh penurunan kemampuan pembayaran pembeli diakui sebagai beban. Kedelapan, Pengakuan denda. Denda dikenakan jika pembeli lalai dalam melakukan kewajibannya sesuai dengan akad dan denda yang diterima diakui sebagai dana kebajikan. Kesembilan, Penyajian persentase piutang murabahah. Piutang murabahah disajikan sebesar nilai neto yang dapat direalisasikan yaitu saldo piutang murabahah dikurangi penyisihan kerugian piutang.

Kesepuluh, penyajian marjin murabahah. Marjin murabahah tangguhan disajikan sebagai pengurang (contra account) piutang murabahah. Kesebelas, Penyajian pembukuan laporan keuangan.Beban murabahah tangguhan disajikan sebagai pengurang (contra account) utang murabahah. Keduabelas, Pengungkapan. (a) Penjual mengungkapkan hal-hal yang terkait dengan transaksi murabahah, tetapi 
tidak terbatas pada: (i) harga perolehan aset murabahah. (ii) janji pemesanan dalam murabahah berdasarkan pesanan sebagai kewajiban atau bukan. (iii)Pengungkapan yang diperlukan sesuai PSAK IOI: Penyajian Laporan Keuangan Syariah. (b) Pembeli mengungkapkan hal-hal yang terkait dengan transaksi murabahah, tetapi tidak terbatas pada: (i) nilai tunai aset yang diperoleh dari transaksi murabahah. (ii) jangka waktu murabahah tangguh.

\section{METODE}

Penelitian ini menggunakan metode pendekatan kualitatif dan kuantitatif dengan pendekatan teknik analisis deskriptif, yaitu data yang diperoleh dan dikumpulkan melalui kuesioner dan wawancara, kemudian dianalisis berdasarkan metode yang telah ditetapkan dan bertujuan untuk menguji sejauh mana penerapan akuntansi PSAK 102 yang diterapkan BMT di kota Depok kemudian menyusun tabulasi data berdasarkan skala ordinal.

Aspek yang diteliti dari penerapan akuntansi adalah komponen perlakuan akuntansi berdasarkan kerangka PSAK I02. Dimana komponen tersebut dijadikan acuan dalam kuesioner penelitian ini. Dalam menentukan BMT yang menjadi obyek dalam penelitian ini, maka melakukan pengambilan obyek dengan pertimbangan tertentu yang disebabkan sulitnya mencari BMT yang masih aktif dalam kegiatan operasionalnya. Pertimbangan ini didasarkan pada kriteria sebagai berikut: (I) BMT yang telah terdaftar dalam administrasi Dinas Koperasi, UMKM dan Pasar Kota Depok. (2) BMT yang telah berdiri selama 5 tahun. (3) BMT yang aktif dalam kegiatan operasionalnya.

Berdasarkan kriteria pemilihan obyek diatas, maka diperoleh BMT yang akan digunakan sebagai obyek dalam penelitian ini adalah sebagai berikut:

\section{Tabel I}

Populasi Penelitian

\begin{tabular}{lc}
\hline \multicolumn{1}{c}{ Kategori } & Jumlah \\
\hline BMT di Kota Depok & 42 \\
BMT yang telah berdiri selama 5 tahun & 25 \\
BMT yang tidak aktif & (I2) \\
Jumlah obyek penelitian & I3 \\
\hline
\end{tabular}

Sumber: Data diolah, 2016

Adapun langkah-langkah dalam pengujian analisis perlakuan akuntansi atas transaksi murabahah di BMT adalah sebagai berikut: (I) Pengujian validitas dan 
reliabilitas. (2) Mengelompokkan jawaban berdasarkan masalah. Dimana dari seluruh jawaban responden atas pertanyaan khusus, dalam hal ini peranan perlakuan akuntansi atas transaksi murabahah di BMT dihitung jumlah jawaban I sampai 5. (3) Selanjutnya untuk setiap jawaban akan diberikan nilai jawaban"SS" nilanya 5, "S" nilainya 4, "KS" nilainya 3, "TS" nilainya 2, dengan catatan adanya bukti dokumen yang terkait jika diperlukan dan jawaban“STS” nilainya I. (4) Menghitung jumlah jawaban I sampai 5 dan banyaknya pertanyaan untuk setiap kelompok. (5) Memasukkan jumlah jawaban I sampai 5 dan jumlah pertanyaan ke dalam rumus indeks. (6) Menghitung besarnya persentase jawaban I sampai 5, untuk setiap kelompok.

Berikut daftar BMT di Kota Depok yang menjadi obyek penelitian:

\section{Tabel 2}

Daftar Sampel penelitian BMT

Nama BMT

Kecamatan

\begin{tabular}{cll}
\hline I & BMT Berkah Madani Gas alam & Cimanggis \\
2 & BMT Al Istiqomah & Cimanggis \\
3 & BMT Al-azhari & Limo \\
4 & BMT Muamalat Mandiri & Pengasinan \\
5 & KUD Soliamitra & Limo \\
6 & BMT Gema Pesona & Tapos \\
7 & BMT QM Sejahtera Mandiri & Margonda \\
8 & BMT Bakti Nurul Huda & Pancoran Mas \\
9 & KJKS Berkah Madani & Kelapa dua \\
I0 & KJKS Multimitra & Bojongsari \\
II & KSU Bina Usaha Sejahtera & Pancoran mas \\
I2 & KSU Syariah Huwaiza & Limo \\
I3 & LKMS Sri Limo & Limo \\
\hline
\end{tabular}

Sumber: Data diolah, 2016

Dari hasil persentase yang didapat, dilakukan interprestasi perlakuan akuntansi atas transaksi murabahah yang efektif ditafsirkan menurut kategori seperti di bawah ini: 
Tabel 3

Persentase Jawaban Responden

\begin{tabular}{cl}
\hline Presentase & \multicolumn{1}{c}{ Interprestasi } \\
\hline $0 \%-19.99 \%$ & Sangat Tidak Setuju \\
$20 \%-39.99 \%$ & Tidak Setuju \\
$40 \%-59.99 \%$ & Kurang Setuju \\
$60 \%-79.99 \%$ & Setuju \\
$80 \%-100 \%$ & Sangat Setuju \\
\hline
\end{tabular}

Sumber: Data Diolah 2016

\section{HASIL DAN PEMBAHASAN \\ Statistik Deskriptif}

Berdasarkan gender maka sebagian besar responden adalah berjenis kelamin "Laki-laki" yaitu sebanyak8 orang, sisanya 5 orang adalah wanita. Berdasarkan latar belakang pendidikan ilmu ekonomi sebanyak 3I\% dengan pengalaman kerja selama 3 tahun dan terdiri dari gender laki-laki kemudian latar belakang pendidikan manajeman dan akuntansi sebanyak 23\% dengan pengalaman kerja selama 2,5 - 2 tahun terdiri dari gender laki-laki dan wanita kemudian latar belakang pendidikan teknik,pai tarbiyah sebanyak 8\% dengan pengalaman kerja selama 3 tahun terdiri dari gender laki-laki dan wanita, dan ilmu pendidikan sebanyak $7 \%$ dengan pengalaman kerja selama I tahun.

\section{Analisis dan Penerapan}

\section{Pengakuan aset murabahah}

Berdasarkan Gambar I Aset murabahah yang diperoleh oleh BMT selalu diakui dalam neraca sebagai persediaan sesuai dengan PSAK I02 paragraf I8 "pada saat perolehan, aset murabahah diakui sebagai persediaan sebesar biaya perolehan "dengan pertanyaan ini di dalam kuesioner, BMT di Depok dengan persentase setuju 69\% dan reponden dengan jawaban sangat setuju I5\% dengan ini dikatakan sudah diterapkan PSAK yang paragraf 18 sudah diterapkan dengan baik di BMT di kota Depok

Indikator aset murabahah persentase setuju dan sangat setuju ini responden berlatar belakang pendidikan akuntansi, ilmu ekonomi dan manajeman serta pengalaman kerja selama 2,5- 3 tahun. Hasil responden dengan dengan setuju 69\% dan sangat setuju I5\% hasil ini sudah melebihi batas ketentuan yang di tentukan $68,4 \%$ batas minimal, sudah diterapkan oleh BMT. 


\section{GambarI \\ Aset Murabahah}

$\square$ sangat tidak setuju $\quad \square$ tidak setuju $\quad$ kurang setuju $\quad \square$ setuju $\quad \square$ sangat setuju

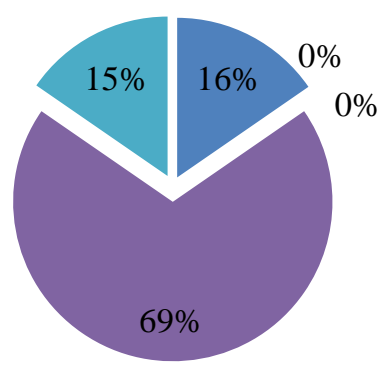

Sumber : Data diolah 2016

Bisa dilihat dari latar pendidikan mereka yang telah menerapkan yaitu akuntansi dimana pengalaman kerja yang lama serta pernah nya BMT perwakilan mengikuti seminar yang di laksanakan lembaga keuangan syariah, membuat responden dengan latar belakang ini telah menerapkan PSAK I02. Latar belakang pendidikan ilmu ekonomi dan manajeman ini karena responden lama bekerja sudah 3 tahun dan hasil wawancara responden menjawab karna mereka sudah biasa menerapkan akun aset ini dengan belajar otodidak awalnya dan pernah mengikuti pelatihan yang diadakan lembaga keuangan syariah.

\section{Pengakuan diskon pembelian}

Berdasarkan Gambar 2, Jika BMT selalu mendapatkan diskon dari supplier setelah terjadinya akad murabahah dengan pembeli, maka diskon akan diakui dalam neraca sebagai kewajiban hasil survei dan kuesioner para responden menjawab kurang setuju dengan persentase 39\% pertanyaan kuesioner ini belum diterapkan di BMT sekota Depok, karena belum sesuai dengan PSAK I02 paragraf 20 "diskon pembelian aset murabahah diakui sebagai pengurang biaya perolehan aset murabahah, jika terjadi sebelum akad murabahah.

Dimana BMT menerapkan tidak selalu dapat diskon dan apabila ada diskon itu akan diberitahukan kepada mitra (nasabah) sebelum pembelian barang yang di pesan oleh mitra (nasabah). Jadi dengan persentase tertinggi kurang setuju dinyatakan PSAK 102 dengan paragraf 20 ini belum diterapkan oleh BMT di Depok. 


\section{Gambar2 \\ Diskon Pembalian}

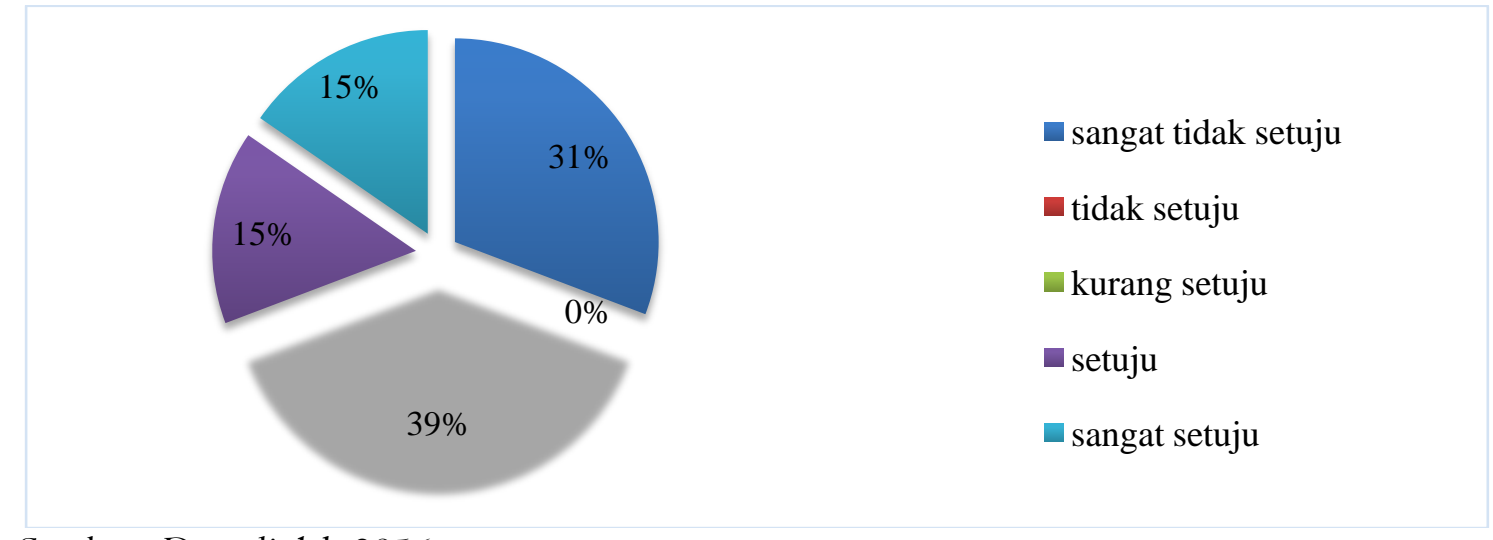

Sumber : Data diolah 2016

Indikator diskon pembelian persentase kurang setuju lebih dominan 39\% dan tidak setuju I5\% ini responden berlatar belakang pendidikan teknik dengan posisi manager, manajemen dengan posisi marketing serta pengalaman kerja selama 2,5 tahun - 3 tahun posisi kerja di BMT di kota Depok tidak bisa semuanya bagian staff accounting karena posisi kerja di BMT merangkap semua pekerjaan di BMT dengan posisi manager harus ikut campur dengan pembuatan laporan keuangan.Dilihat dari hasil responden menjawab jawaban setuju dan sangat setuju cuma mencapai 30\% dimana pertanyaan ini belum diterapkan di BMT karena dilihat dari latar belakang pendidikan responden BMT ada yang berlatar pendidikan marketing dimana posisi ini belum bisa dikatakan posisi yang cocok untuk penerapan PSAK IO2 dimana latar belakang seperti acounting setidaknya bisa memahami akun-akun akuntansi.

Sedangakan responden dengan pertanyaan ini marketing sebagai responden kurangnya pemahaman tentang penerapan PSAK karena responden ini jarang adanya pelatihan dan ilmu pengetahuan responden hanya sebatas diberitahukan oleh bagian yang membuat laporan keuangan. Dimana telah dijelaskan di atas posisi yang ada di BMT merangkap semua pekerjaan karena ruang lingkup mereka masih kecil dan memperkerjakan SDM juga terbatas.

\section{Pengakuan kemampuan pembayaran}

Berdasarkan Gambar 3 Jika nasabah selaku pembeli mengalami penurunan kemampuan pembayaran maka pihak BMT akan memberikan potongan angsuran dan diakui sebagai beban. Hasil survei dan kuesioner menyatakan responden menjawab sangat setuju dengan persentase 39\% dimana batas dinyatakan responden telah menerapkan pertayaan kuesioner dengan batas 68,4\% ini dinyatakan pertanyaan ini belum diterapkan oleh BMT di depok sesuai dengan PSAK 102 paragraf 28 "potongan murabahah diakui sebagai berikut jika 
Penerapan PSAK NO. I02 Atas Transaksi Murabahah: Studi Pada Baitul Maal Wa Tamwil Di Depok, Jawa Barat

(Rani Febrian ${ }^{1}$, Sepky Mardian²)

disebabkan oleh penurunan kemampuan pembayaran pembeli, maka diakui sebagai beban".

\section{Gambar3}

Kemampuan pembayaran Murabahah

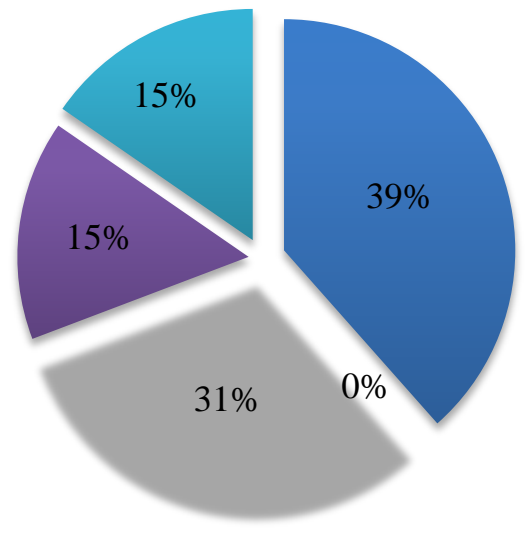

- sangat tidak setuju

tidak setuju

kurang setuju

setuju

sangat setuju

Sumber : Data diolah 2016

Responden menjawab kurang setuju karena kebanyakan mitra (nasabah) hanya mencari alasan untuk mempermudah diri dan apabila BMT sudah mengasih peluang nasabah menjadi lalai dengan kelongaran yang diberikan BMT.Responden yang menjawab kuesioner ini dengan latar belakang pendidikan SMK Perbankan Syariah dengan lama bekerja I tahun, teknik dengan lama bekerja 3 tahun dan ilmu ekonomi dengan lama bekerja 3 tahun.

Dengan hasil wawancara dengan responden yang berlatar belakang SMK Perbankan Syariah ini menyatakan bahwasannya mereka belum menerapkan dengan baik pertanyaan dengan indikator ini karena pemahaman mereka hanya sekedar membuat laporan keuangan yang telah ditentukan, dan penulis melihat laporan keuangan tidak lengkap seperti laporan keuangan BMT yang telah menerapkan PSAK I02.Latar pendidikan mereka serta pengalaman kerja hanya baru I tahun bisa dikatakan responden belum berpengalaman dengan laporan keuangan dimana ditujukan kepada PSAK I02 dan responden masih awam dengan PSAK IO2 yang sesuai dengan PSAK itu sendiri, maka dari itu reponden belum mengerti menerapkan harus seperti apa semestinya.

\section{Pengukuran dasar}

Berdasarkan Gambar 4 Pengukuran aset pesanan mengikat yang dipesan nasabah kemudian terjadi penurunan nilai barang karena rusak atau kualitasnya maka transaksi ini sebagai kerugian penjual (BMT). 


\section{Gambar4 \\ Dasar Pengukuran}

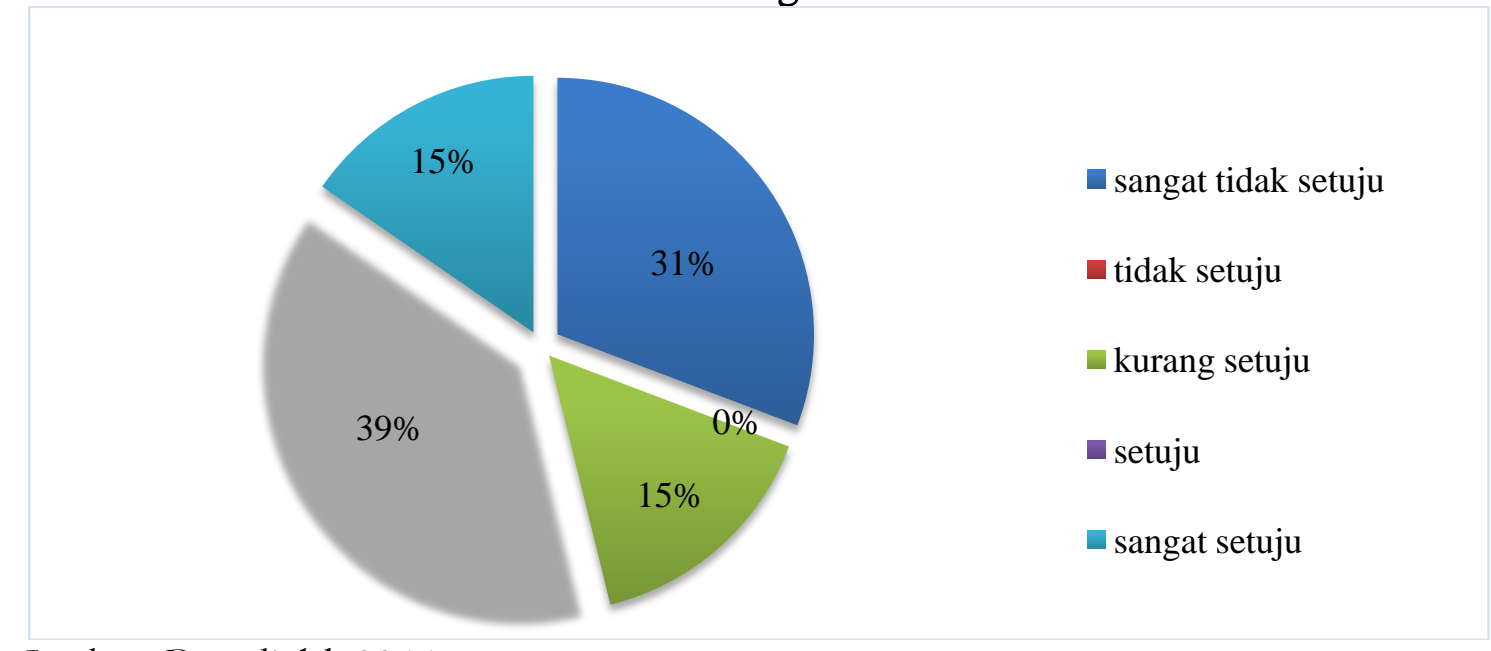

Sumber : Data diolah 2016

Hasil survei dan kuesioner menyatakan jawaban responden setuju 39\% dan sangat setuju 3I\% belum memenuhi persentase yang telah di tentukan yaitu 68,4\% baru bisa dinyatakan BMT telah menerapkan PSAK IO2 sesuai dengan PSAK I02 paragraf 19 "pengukuran aset murabahah setelah perolehan adalah sebagai berikut jika murabahah pesan mengikat, maka dinilai sebesar biaya perolehan dan jika terjadi penurunan nilai aset karena usang, rusak, atau kondisi lainnya sebelum diserahkan ke nasabah, penurunan nilai tersebut diakui sebagai beban dan mengurangi nilai aset”. Responden menganggap pertanyaan ini kerugian ditanggung berdua bukan hanya satu sisi yang menanggung kerugian. Karena responden ini berlatar belakang pendidikan SMA dengan pengalaman kerja 2 tahun dan ilmu ekonomi dengan lama bekerja 3 tahun.Dilihat dari hasil wawancara dengan responden yang berlatar pendidikan SMA ini belum bisa dikatakan dengan baik untuk pencatatan sebuah lembaga dan responden mengatakan BMT tempat dia bekerja belum pernah mengadakan pelatihan khusus untuk SDM mencatat laporan keuangan yang seharusnya.

Responden menyatakan pembuatan laporan keuangan hanya sebatas dengan pengetahuan yang seadanya saja.Disini responden SDM berfikir dengan belajar dan memahami PSAK 102 itu masih digolongkan sulit untuk dipahami dan diterapakan karena bahasa yang terlalu tinggi dan latar pendidikan mereka belum mendukung karena itu sebab pernyataan ini belum diterapkan dengan baik.

\section{Pengukuran murabahah pesanan}

Berdasarkan Gambar 5, Ketika pembelian barang kepada supplier BMT mendapatkan diskon biaya asuransi, diskon tersebut tidak diberikan kepada 
pembeli (nasabah) karena tidak selalu mendapat diskon seperti itu. Hasil survei dan kuesioner menyatakan setuju dengan responden 39\% belum memenuhi persentase yang telah di tentukan yaitu 68,4\% baru bisa dinyatakan BMT telah menerapkan PSAK 102 sesuai dengan PSAK 102 paragraf 34 "diskon pembelian yang diterima setelah akad murabahah, potongan pelunasan, dan potongan untung murabahah diakui sebagai pengurang beban murabahah tangguhan” dan PSAK I02 paragraf I9 murabahah pesanan.

\title{
Gambar5
}

\section{Murabahah Pesanan}

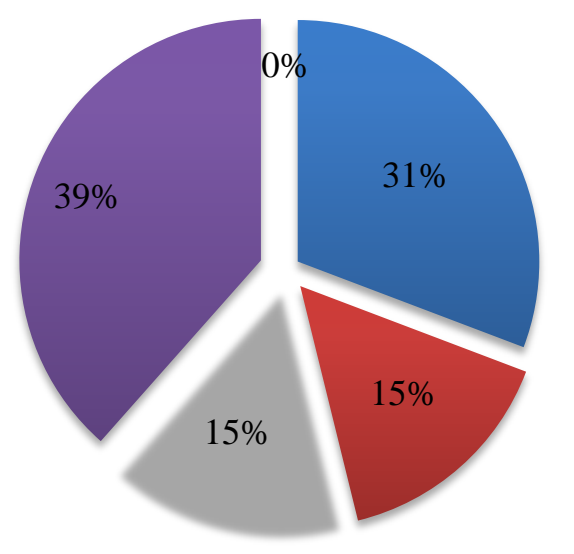

\author{
- sangat tidak setuju \\ tidak setuju \\ kurang setuju \\ setuju \\ sangat setuju
}

Sumber: Data diolah 2016

Disini responden lebih dominan menjawab kurang setuju karna ketika BMT mendapat diskon apapun akan diberi tahukan kepada mitra (nasabah) yang pesanan jadi pertanyaan yang dikuiesoner belum diterapkan oleh BMT. Dengan latar belakang pendidikan responden yaitu manajemen dengan lama bekerja 3 tahun, SMK perbankan syariah dengan pengalaman kerja I tahun, ilmu ekonomi dengan pengalaman kerja 2,5 tahun, pendidikan dengan pengalaman kerja I tahun.

Dari hasil wawancara dengan responden yang berlatar pendidikan SMK Perbankan Syariah responden mengatakan kurangnya fasilitas untuk memahami PSAK karena belum pernah di adakannya pelatihan khusus untuk pembuatan laporan keuangan sesuai dengan PSAK I02 di BMT tempat responden bekerja salain sisi pengalaman kerja respon yang belum lama yaitu satu tahun dimana untuk memahami dan bisa secara benar butuh waktu yang lama untuk menerapakan dengan benar. Karena responden mengatakan untuk memahami PSAK itu tidak mudah dengan latar pendidikan responden ini. Sama juga dengan responden yang backgraund pendidikan. 


\section{Penyajian persentase piutang murabahah}

Berdasarkan Gambar 6, Piutang murabahah disajikan sebesar saldo piutang murabahah dikurangi penyisihan kerugian piutang. Hasil survei dan kuesioner menyatakan responden menjawab setuju dengan responden 39\% dan sangat setuju I5\% belum memenuhi persentase yang telah ditentukan yaitu $68,4 \%$ baru bisa dinyatakan BMT telah menerapkan PSAK I02 sesuai dengan PSAK I02 paragraf 37 "piutang murabahah disajikan sebesar nilai neto yang dapat direalisasikan, yaitu saldo piutang murabahah dikurangi penyisihan kerugian piutang" karena responden latar belakang pendidikan manajeman dengan pengalaman kerja 3 tahun, pendidikan dengan lama bekerja I tahun, ilmu ekonomi lama bekerja 3 tahun.

\section{Gambar6}

Persentase Piutang Murabahah

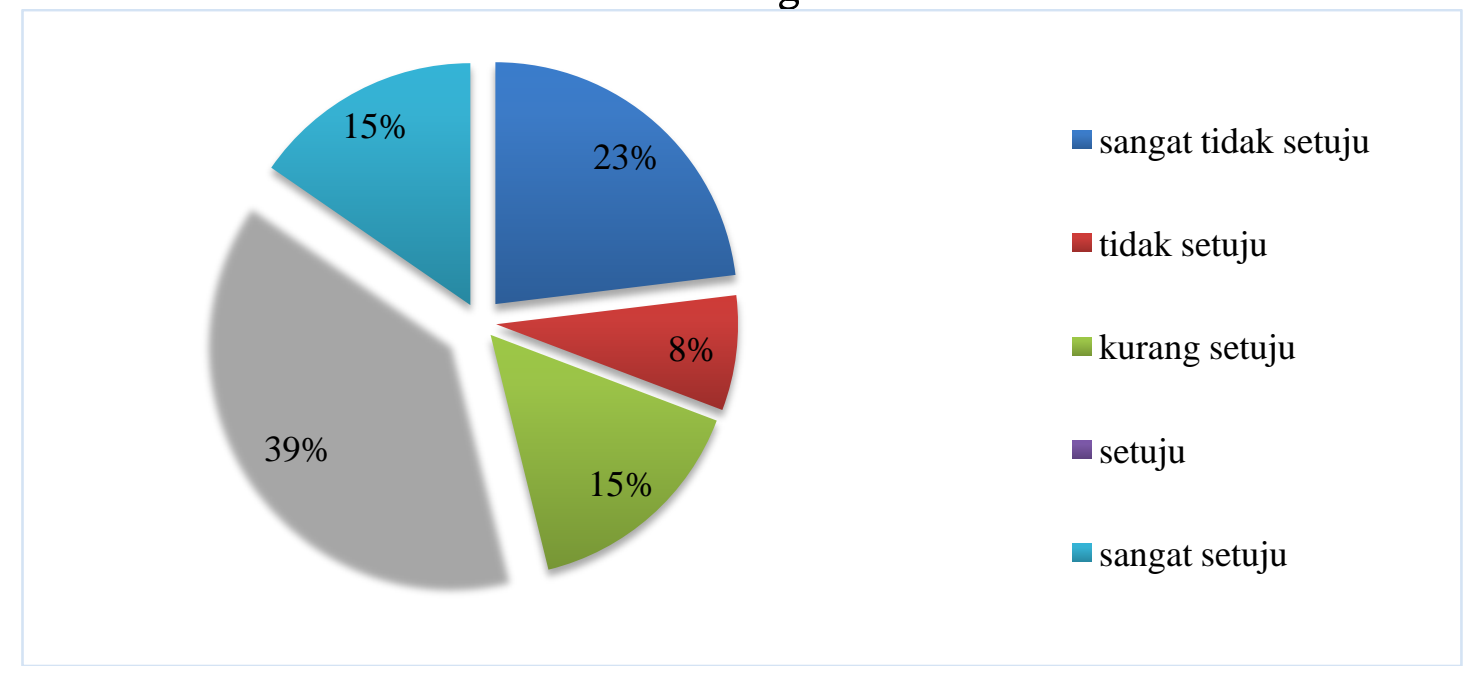

Sumber : Data diolah 2016

Hasil wawancara dengan responden yang menjawab ini berlatar belakang pendidikan manajeman dan ilmu ekonomi responden memaparkan kepada peneliti bahwasannya di BMT tempat responden bekerja belum menerapakan pertanyaan seperti ini dan pemahaman dengan PSAK belum tepat dilakukan responden, sedangkan pertanyaan dengan isi PSAK I02 ini harus nya responden setuju tetapi hasil dari lapangan respon kurang memahami PSAK I02 dengan baik dengan alasan responden memahami PSAK I02 itu sulit dan jarang di adakannya pelatihan khusus di tempat responden bekerja.

\section{Penyajian marjin murabahah}

Berdasarkan Gambar 7, BMT menyajikan marjin sebagai pengurang piutang murabahah. Hasil survei dan kuesioner dengan jawaban setuju dengan responden $54 \%$ dan sangat setuju $8 \%$ baru mencapai $66 \%$ setuju dengan sangat setuju 
digabungkan hampir mendekati persentase yang telah di tentukan yaitu $68,4 \%$ baru bisa dinyatakan BMT telah menerapkan PSAK I02 sesuai dengan PSAK I02 paragraf 38 "marjin murabahah tangguhan disajikan sebagai pengurang (contra account) piutang murabahah”. Dimana responden berlatar belakang pendidikan pai tarbiayah dengan lama bekerja 3 tahun, manajeman lama bekerja 3 tahun, ilmu ekonomi pengalaman kerja 3 tahun

\section{Gambar7 Marjin Murabahah}

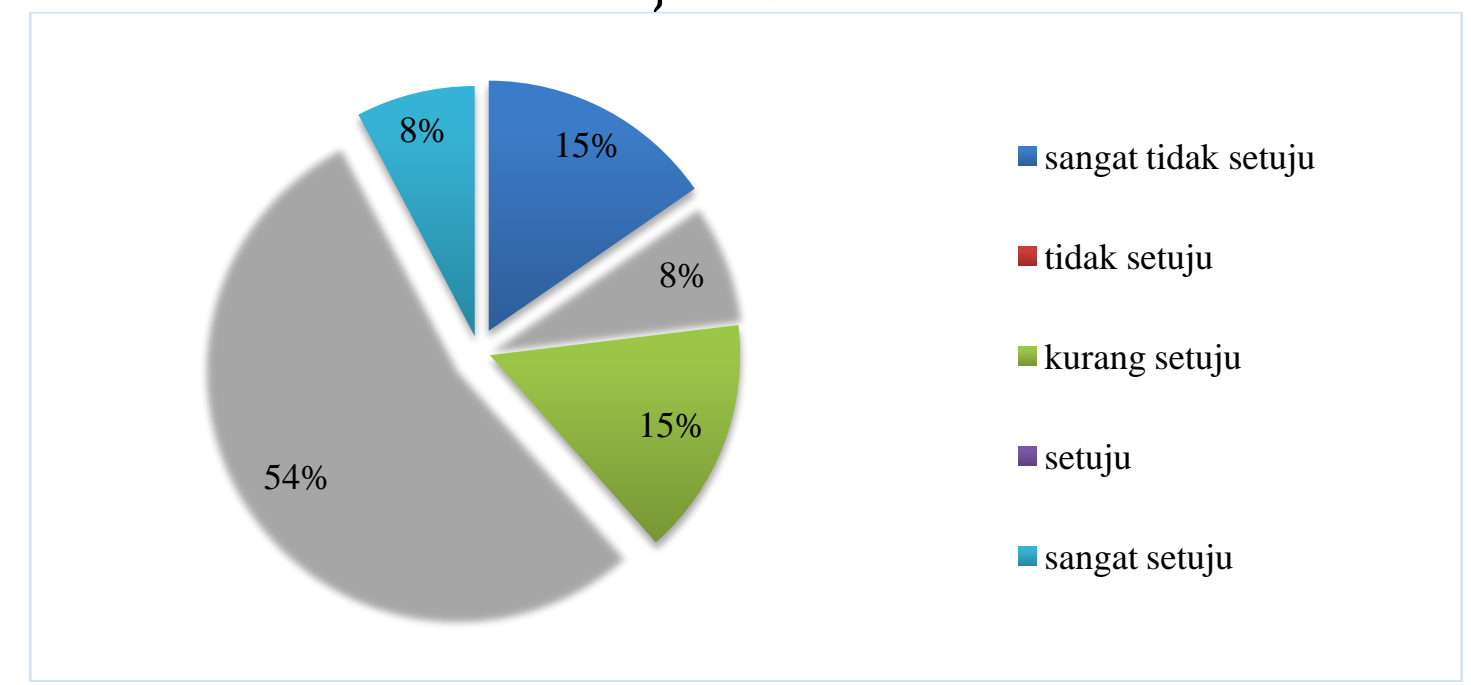

Sumber : Data diolah 2016

Hasil wawancara dengan responden yang menjawab dengan latar belakang pendidikan pai tarbiyah ini menyatakan sistem di BMT responden kerja sudah menerapkan PSAK 102 dengan baik serta dilihat dari pengalaman kerja responden dengan latar pendidikan pai tarbiayah ini, banyak mendapat link dengan BMT lain dan pernah BMT tempat responden bekerja melakukan seminar per periode atau sekali 4 bulan. Suatu kelebihan yang dimiliki oleh responden dengan jawaban ini karena dilihat dari latar belakang responden ternyata di lapangan responden ini telah menerapkan pertanyaan indikator ini.

\section{Pengungkapan CALK}

Berdasarkan Gambar 8, BMT tempat saya bekerja telah sesuai melakukan pembukuan catatan atas laporan keuangan. Hasil survei dan kuesioner menyatakan responden dengan jawaban setuju mencapai $54 \%$ dan sangat setuju banyak responden menjawab $46 \%$ sudah memenuhi persentase yang telah ditentukan yaitu 68,4\% bisa dinyatakan BMT telah menerapkan PSAK I02 sesuai dengan PSAK 
102 paragraf 40 (c) "pengungkapan yang diperlukan sesuai PSAK I02 : penyajian laporan keuangan syariah”. Dimana BMT membuat Catatan Atas Laporan Keuangannya seperti dijabarkan transaksi apa saja yang terjadi di setiap transaksi. Reponden menjawab pertanyaan kuesioner ini dengan latar belakang akuntansi pengalaman kerja 2,5 tahun, ilmu ekonomi,manajeman dengan lama bekerja selama 3 tahun.

\section{Gambar8}

\section{Catatan Atas Laporan Keuangan}

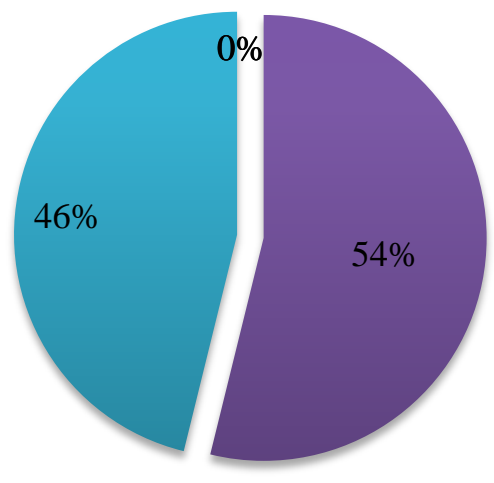

- sangat tidak setuju

tidak setuju

- kurang setuju

setuju

- sangat setuju

Sumber : Data diolah 2016

Dilihat dari hasil wawancara dengan responden yang menjawab pertanyaan yang ada di dalam kuesioner ini menyatakan dengan latar pendidikan akuntansi wajar dengan menjawab setuju dan sangat setuju dimana SDM dengan latar belakang pendidikan akuntansi sudah mengetahui apa itu catatan atas laporan keuangan dan responden setuju dengan pertanyaan ini.Latar belakang pendidikan ilmu ekonomi dan manajeman responden menyatakan pengalaman kerja yang sudah lama dan pengetahuan mereka bertambah dengan cara kursus, serta waktu kursus disedikan di responden mengatakan mereka kursus di waktu libur.

\section{Pengungkapan peran accounting}

Hasil survei dan kuesioner responden menjawab dengan jawaban setuju sebanyak 54\% dan sangat setuju responden menjawab sebanyak 46\% sudah memenuhi persentase yang telah ditentukan yaitu $68,4 \%$ bisa dinyatakan BMT telah menerapkan PSAK sesuai dengan PSAK IO2 paragraf 40 (b) "penjual mengungkapkan hal-hal yang berkaitan dengan transaksi murabahah tetapi tidak 
Penerapan PSAK NO. I02 Atas Transaksi Murabahah: Studi Pada Baitul Maal Wa Tamwil Di Depok, Jawa Barat

(Rani Febrian ${ }^{1}$, Sepky Mardian²)

terbatas pada janji pemesan dalam murabahah berdasarkan pesanan sebagai kewajiban " disini BMT peran accounting atau pengurus sebagai manajer juga berperan didalam pembuatan laporan keuangan bisa dikatakan ikut menyetujui pembuatan laporan keuangan jadi pertanyaan ini sesuai dengan PSAK I02.

\section{Gambar9 \\ Peran Accounting terhadap Laporan Keuangan}

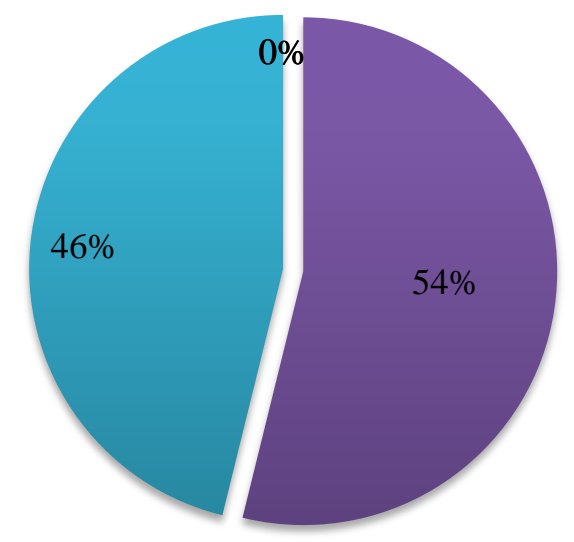

- sangat tidak setuju

tidak setuju

kurang setuju

$\square$ setuju

sangat setuju

Sumber : Data diolah 2016

Responden yang menjawab pertanyaan kuesioner dengan latar belakang pendidikan akuntansi pengalaman kerja 2,5 tahun, ilmu ekonomi,manajeman dengan lama bekerja selama 3 tahun, teknik dan pai tarbiayah dengan pengalaman kerja 3 tahun dengan posisi jabatan pengurus dan manajer.Responden menyatakan penerapan dengan pertanyaan yang ada di kuesioner ini telah sesuai karena responden ini mengerti dengan pernyataan di dalam PSAK I02 karena menurut responden penyataan yang ada di dalam PSAK sudah tidak asing bagi responden dan pengalaman kerja responden yang cukup lama di BMT tempat responden bekerja.

\section{Pengungkapan kebijakan akuntansi}

Berdasarkan Gambar I0, Dalam mengungkapkan kebijakan akuntansi untuk pengguna laporan keuangan, manajeman selalu mengungkapkan persediaan. Hasil survei dan kuesioner responden dengan jawaban setuju sebanyak 54\% dan jawaban sangat setuju sebanyak $46 \%$ sudah memenuhi persentase yang telah di tentukan yaitu 68,4\% bisa dinyatakan BMT telah menerapkan sesuai PSAK IO2 paragraf 40 
(a) "penjual mengungkapkan hal-hal yang terkait dengan transaksi murabahah, tetapi tidak terbatas pada harga perolehan aset murabahah "dimana kebijakan akuntansi untuk membantu pengguna laporan keuangan lebih mudah hasil pertanyaan ini setuju itu tandanya mereka sudah menerapkan psak IO2 di BMT kota Depok.

\section{GambarI0}

Kebijakan Akuntansi

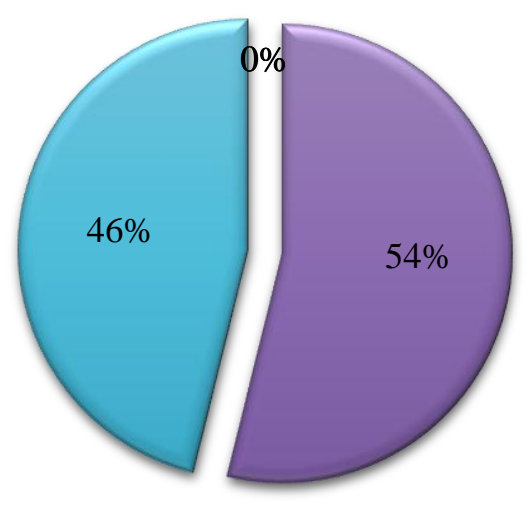

$\square$ sangat tidak setuju
$\square$ tidak setuju
$\square$ kurang setuju
$\square$ setuju
$\square$ sangat setuju

Sumber : Data diolah 2016

Dengan hasil wawancara dengan responden teknik mengatakan mereka bisa menerapkan pertanyaan ini dengan pengalaman kerja responden di BMT tempat responden bekerja jadi responden sudah tidak asing dengan PSAK I02 yang di terapkan di laporan keuangan serta adanya pelatihan dan seminar yang di adakan di BMT responden bekerja jadi responden sudah menerapkan pernyataan ini.

\section{Pengungkapan informasi transaksi murabahah}

Berdasarkan Gambar II, Ketika manejer memberikan informasi yang dinilai material dapat membantu pengguna laporan keuangan. Hasil survei dan kuesioner responden dengan jawaban setuju lebih dominan sebanyak 69\% dan jawaban sangat setuju responden menjawab sebanyak 3I\% sudah memenuhi persentase yang telah ditentukan yaitu 68,4\% bisa dinyatakan BMT telah menerapkan PSAK dengan pertanyaan kuesioner ini informasi yang diungkapkan manager ini dinyatakan telah diterapkan di BMT kota Depok yang sesuai dengan PSAK I02 paragraf 40 "penjual mengungkapkan hal-hal yang terkait dengan transaksi murabahah" dimana informasi yang tepat dan material yang disampaikan meneger akan membantu pekerjaan accounting dan pembaca laporan keuangan. 


\section{GambarII \\ Informasi transaksi murabahah}

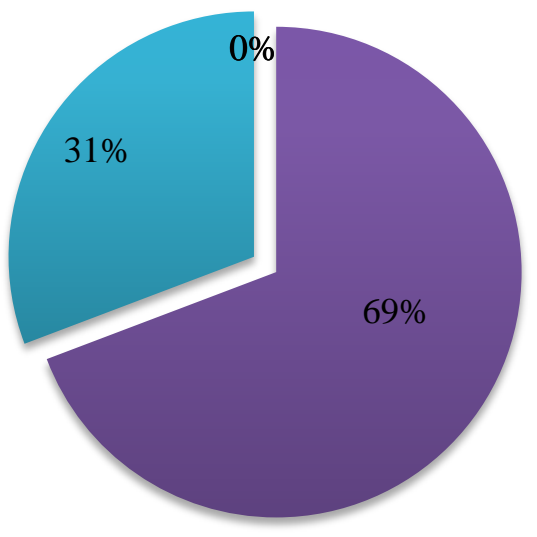

- sangat tidak setuju

- tidak setuju

- kurang setuju

- setuju

ש sangat setuju

Sumber : Data diolah 2016

Dengan ini pertanyaan di kuesioner ini responden yang menjawab dengan latar pendidikan akuntansi pengalaman kerja 2,5 tahun, ilmu ekonomi,manajeman dengan lama bekerja selama 3 tahun. Teknik dan pendidikan dengan lama bekerja 3 tahun. PAI Tarbiayah dan posisi sebagai staf akuntansi dengan pengalaman kerja selama 3 tahun.Dilihat dari hasil wawancara dengan responden yang menjawab pertanyaan yang ada di dalam kuesioner menyatakan mereka telah menerapkan indikator yang peneliti tanyakan kepada responden karena responden pengalaman kerja sudah cukup lama dan latar pendidikan responden juga mendukung untuk penerapan PSAK IO2 ini responden mengatakan untuk bisa menerapkan transaksi murabahah sesuai PSAK I02 responden ada yang menambah belajar dengan cara kursus di tempat lain. Responden dengan menjawab setuju dan sangat setuju sudah memenuhi persentase yang telah di tentukan yaitu $68,4 \%$ bisa dinyatakan BMT telah menerapkan PSAK.

Pratiwi dan Septiarini (2014) menemukan bahwa masih terdapat beberapa hal yang tidak sesuai dengan PSAK 102 pada BMT Rahmat Syariah. Dalam hal pengakuan, pengukuran, penyajian, dan pengungkapan terhadap transaksi awal akad tidak sesuai dengan PSAK I02. Selain itu dalam hal pengukuran keuntungan murabahah juga tidak sesuai dengan PSAK I02. Pada saat pelunasan telah sesuai dengan PSAK I02, namun pengakuan, penyajian, dan pengungkapan tidak sesuai dengan PSAK I02. Dengan ini PSAK I02 yang ada di BMT belum semuanya melakukan pencatatan yang sesuai dengan akun-akun yang telah ditentukan PSAK. Habibah (2016) mengidentifikasikan bahwa masih terdapat BMT yang melakukan pengakuan persedian yang seharusnya tidak perlu dilakukan. Selain itu, pihak BMT 
belum memperlihatkan nilai cadangan kerugian piutang murabahah.Hariyanto (20I5) menyebutkan bahwa sebagian besar perlakuan akuntansi murabahah telah sesuai dengan PSAK No. I02 pada BMT Ummah.

Hal berbeda ditemukan Zakiah dan Riduwan (2013) pada perlakuan PSAK I02 di Bank Syariah Mandiri. Secara garis besar penerapan akad murabahah pada pembiayaan kepemilikan rumah telah sesuai dengan PSAK No. I02. Parno dan Tikawati (2016) menemukan bahwa secara garis besar perlakuan akuntansi yang dilakukan oleh KPN IAIN Samarinda telah sesuai dengan prinsip akuntansi yang diterima umum yaitu PSAK No. 102.

\section{E. SIMPULAN}

Berdasarkan hasil penelitian dan analisis data, maka penulis menarik kesimpulan sebagai berikut. Dari I3 BMT di Kota Depok yang telah menerapkan PSAK 102 atas transaksi murabahah. Penerapan PSAK I02 yang terbagi menjadi empat komponen dimana setiap kompenen tersebut telah diterapkan oleh BMT di Kota Depok yang menjadi objek penelitian ini, meskipun tidak seluruhnya. Kemudian jika dirata-ratakan jawaban responden di BMT tersebut yang telah menerapkan PSAK I02 sebesar 68,4\%dan yang belum menerapkan PSAK IO2 sebesar 31,6\%. Sehingga dapat disimpulkan bahwa I3 BMT di Kota Depok ratarata telah menerapkan PSAK I02 atas transaksi murabahah.

\section{PUSTAKA ACUAN}

Azharuddin. (20I4). Konsep dan Aplikasi Akad Murabahah pada Perbankan Syariah. Jakarta: Masyarakat Ekonomi Syariah (MES).

Didiek, A. (2013). Sistem Lembaga Keuangan Ekonomi Syariah Dalam Pemberdayaan Ekonomi Rakyat. Semarang: PT. Pustaka Rizki Putra.

Habibah, M. (2016). Analisis Penerapan Akuntansi Syariah Berdasarkan PSAK

I02 Pada Pembiayaan Murabahah di BMT Se-Kabupaten Pati. Equilibrium: Jurnal Ekonomi Syariah, Vol. 4 (I): I I4-I36.

Hariyanto. (20I5). Perlakuan Akuntansi Syariah PSAK Nomor I02 Pada BMT

Ummah Banjarmasin. Al-Banjari, I4 (2): I85-I93.

IAI. (2009). Standar Akuntansi Keuangan per I juli 2009. Jakarta: 2009.

IAI. (2013). PSAK I02 edisi revisi . Jakarta: Salemba Empat.

Mustofa, A. D. (20I4). Reorientasi Ekonomi Syariah. Yogyakarta: UII Press Yogyakarta (Anggota IKAPI). 
Penerapan PSAK NO. I02 Atas Transaksi Murabahah: Studi Pada Baitul Maal Wa Tamwil Di Depok, Jawa Barat

(Rani Febrian ${ }^{1}$, Sepky Mardian²)

Parno dan Tikawati. (2016). Analisis Penerapan PSAK No. I02 Untuk Pembiayaan Murabahah Pada KPN IAIN Samarinda. el-Jizya, 4 (2): 285316.

Pratiwi, I.E. dan Septiarini, D.F. (20I4). Analisis Penerapan PSAK -I02 Murabahah (Studi Kasus Pada KSU BMT Rahmat Syariah Kediri. Akrual: Jurnal Akuntansi, 6 (I): 17-32.

Wardiwiyono, S. (2012). Internal Control System for islamic Micro Financing (An Explatory Study of BMT in the City of Yogyakarta Indonesia). International Journal of Islamic and Middle Eastern Finance and Management Vol.5 No.4 , 340-352.

Zakiah dan Riduwan, A. (2013). Akuntansi Transaksi Pembiayaan Kepemilikan Rumah Dengan Akad Murabahah. Jumnal Ilmu dan Riset Akuntansi, 2 (6): I-I6. 